ARTICLE

Check for updates

\title{
WORLD TRADE FLOWS IN XX CENTURY
}

\author{
IBRAHIMI, Agron ${ }^{a}$; JANKOVIC, Marija ${ }^{b}$ \\ a) Faculty of economics and business, University Mediterranean, Podgorica, Montenegro \\ b) Faculty of economics and business, University Mediterranean, Podgorica, Montenegro. Corresponding Author \\ (marija.jankovic.mbs@gmail.com)
}

\author{
PUBLISHED: 10/11/2021
}

Accepted: 04/11/2021

Submitted: 12/10/2021

\section{COPYRIGHT NOTICE:}

\section{CITE THIS PAPER:}

Ibrahimi, Agron; Jankovic, Marija (2021). "World Trade Flows in XX Century" Journal of World Economy:

Transformations \& Transitions (JOWETT) 1(02):07. DOI: https://doi.org/10.52459/jowett1271121

\begin{abstract}
International trade represents the exchange of goods and services across state borders. In most countries, it forms a significant part of Gross Domestic Products (GDP). Although international trade has been presented throughout history, its economic, social, and political importance has increased in recent centuries, mainly due to industrialization, transport development, globalization, and multinational corporations. The work is planned methodologically to be explored through the graphic method, the method of index numbers and the average annual rate of change, and the trend method. The analysis of work is divided over the period. The first period is considered from 1948-1999, the second period from 1980-1999. In the 20th century, there were significant changes in the structure of international trade. By the 1960s, dominant products in international trade were primary products (raw materials), while from that period the international trade was dominated by industrial products.
\end{abstract}

\section{KEYWORDS}

World Trade, Gross Domestic Product, Goods, Exports, Imports. 


\section{INTRODUCTION}

Theories of international trade appeared to answer the question of why countries trade with each other, as well as other questions about what a country produces, what will export, and at what cost, what profits are generated by international trade, and how they are allocated between countries.

Foreign trade is characterized by the transition of the trade-political border of a particular region or country. Geographical and cultural distances between countries are permanently reduced due to the expansion of technical and technological development, enabling companies to significantly expand the market and sources of raw materials.

International trade flows are of great importance from the standpoint of the development of economies and regions. In a way, they can be considered as the crucial factor of the economic growth of a particular economy. No economy can build its growth on the self-sufficiency of real and financial resources, and therefore it resorts to international trade, where the final balance reflects the degree of growth and macroeconomic variables of an economy. Thus, the import of certain products and services into a country is adversely affected by the external trade balance and requires the engagement of financial resources for its coverage, causes an increase of debt, affects the exchange rate, and through prices of imported products has an impact on inflation in that country. Conversely, the export of products and services enhances the level of resource utilization in a country, financial resources are provided without the growth of indebtedness with some other benefits that consequently arise within the domestic economy. These are just some of the implications that international trade flows can have on a particular economy (Balšić, 2014).

\section{REVIEW OF SCIENTIFIC LITERATURE}

International exchange is due to (and under the influence of) the difference in comparative costs. Why are different comparative advantages between countries? The Swedish economist, Eli Heckscher, tried to answer this question in 1919, and then his student Bertil Olin (Bertil Ohlin) in 1933. Their study was supplemented by American economist Paul Samuelson (Paul Samuelson), and this is why this theory is called the HeckscherOlin-Samuelson model (the so-called H.O.S. model). This theory belongs to the neoclassical theory of international trade and is called the standard theory of international trade.

These scientists have proven that by applying the theory of comparative advantages, more expensive domestic products are replaced by cheaper imports and that domestic products are more expensive to sell in the world than on the domestic market. The most successful representative among these economists is Swedish Bertil Olin, winner of the Nobel Prize for Economics for 1977. He presented his views in the Interregional and International Trade section. 
Olin did not completely reject Ricard's conception but accepted the theory of comparative costs (Ohlin, 1933). However, he noticed differences by comparing certain types of costs in individual countries, depending on which production factors each of them has. Abundant factors are relatively cheap, and scarce factors are rallying more expensive in every part of the world. Goods that require a lot for the first production, and a bit of that long, are exported in exchange for goods looking for factors in reverse (opposite) proportions. And, therefore, indirect factors that are abundantly exported, and factors that are scarce in the offer, are imported. (Rybczynski, 1955).

American economist Paul Samuelson supplemented Olin's theory by introducing differences in taste and demand. He asked whether the trade would come to be between two countries where production costs and prices are identical (Samuelson, 1948). In his opinion, the store will also come in that case, because there are differences in tastes in individual countries. He cited the example of Norway and Sweden, which can produce fish and meat at roughly the same costs. However, since the Swedes prefer meat and Norwegian fish, they will export fish from Sweden to Norway, and vice versa, to the export of meat from Norway to Sweden (Samuelson, 1949)

\section{RESEARCH METHODOLOGY}

In this research, we have used the methods of dynamic analysis to investigate and analyze the changes in the phenomenon during the time. In the analysis of time series (Resić, 2012), the following methods are commonly used: graphic method, index number method, and the average annual rate of change of trend method. The graphic method (line and staircase graphics) is a very useful tool, which provides a general picture of the data of a time series that becomes concise and transparent.

The method of index numbers is very important in dynamic analysis. They express relative changes in time. They are calculated by comparing the level of the phenomenon of one period with the magnitude of the occurrence in another period.

We distinguish the base index numbers (index numbers with a fixed base) by comparing all the members of the time series with one of its members. The member with which we compare is the basis of the comparison, then chain index numbers (index numbers with a variable base) if each member of the time series is compared with the previous member of the string. When the geometric mean of chain indexes is reduced by 100 , we get the average annual rate of change based on which we can make projections.

The trend method is used to monitor the long-term development of the phenomenon. The trend implies the basic flow of the movement of the phenomenon over a longer period, as a legitimate (average) movement when the changes of the phenomenon are even. 
The smallest square method provides the ability to determine the model that will most adequately express the movement of the given phenomenon and is reduced to finding a mathematical function whose values are the closest to the values of the time series that is the subject of the analysis. We proceed from the assumption that the observed series best approximates a function whose deviation from this series is minimal (the sum of the deviation squares is the smallest). Therefore, it is a specific form of a regression model where time is an independent variable.

\section{EMPIRICAL DATA AND ANALYSIS}

When we observe the trend of the development of World Trade by regions and countries for the period from 1948 to1999, we can notice that the growth of the value of imports follows the growth of the value of exports and that they have predominantly a tendency of growth from year to year. The countries of the General Agreement on Tariffs and Trade / World Trade Organization (GATT / WTO) and Western Europe are the leaders of import and export and occupy the largest share in world trade of goods for the specified period.

Table no. 1, made by authors based on the WTO statistics (International trade statistics, 2000) shows that Asia has overtaken North America in exports since 1983, while before that year, North America had primacy in exports. Also, we can conclude that the Six East Asian trader countries (Taiwan (China), Hong Kong (China), Malaysia, South Korea, Singapore, Thailand) from 1963 until 1999 lagged behind Japan in exports despite the previous indicators. When it comes to imports, the Six East Asian trader countries are leading in imports compared to Japan since 1993. Asia from 1983 to 1993 had a growing tendency of import, while North America after that period assumed the role of the "import leader" which had before 1983. From the other regions, Australia, and New Zealand in 1999 had the least import share of $1.5 \%$ and exports of $1.3 \%$.

Table no. 1: World trade of goods by regions and countries 1948-1999 (in bln. \$ and \%) 


\begin{tabular}{|c|c|c|c|c|c|c|c|}
\hline & 1948 & 1953 & 1963 & 1973 & 1983 & 1993 & 1999 \\
\hline \multicolumn{8}{|c|}{ Export } \\
\hline \multirow{3}{*}{ World } & & & & Value & & & \\
\hline & 58.0 & 83.0 & 157.0 & 578.0 & 1835.0 & 3639.0 & 5473.0 \\
\hline & \multicolumn{7}{|c|}{ Share } \\
\hline World & 100 & 100.0 & 100.0 & 100.0 & 100.0 & 100.0 & 100.0 \\
\hline North America & 27.5 & 24.6 & 19.4 & 17.2 & 15.4 & 16.8 & 17.1 \\
\hline Latin America & 12.3 & 10.5 & 7.0 & 4.7 & 5.8 & 4.4 & 5.4 \\
\hline Western Europe & 31.0 & 34.9 & 41.0 & 44.8 & 39.0 & 43.7 & 43.0 \\
\hline
\end{tabular}

\section{C./E. Europe/Baltic State/ CIS}

\begin{tabular}{|c|c|c|c|c|c|c|c|}
\hline a & 6.0 & 8.2 & 11.0 & 8.9 & 9.5 & 2.9 & 3.9 \\
\hline Africa & 7.4 & 6.5 & 5.7 & 4.8 & 4.4 & 2.5 & 2.0 \\
\hline Middle East & 2.1 & 2.1 & 3.3 & 4.5 & 6.8 & 3.4 & 3.1 \\
\hline Asia & 13.8 & 13.2 & 12.6 & 15.0 & 19.1 & 26.3 & 25.5 \\
\hline Japan & 0.4 & 1.5 & 3.5 & 6.4 & 8.0 & 10.0 & 7.7 \\
\hline China & 0.9 & 1.4 & 1.3 & 1.0 & 1.2 & 2.5 & 3.6 \\
\hline Australia and New Zealand & 3.7 & 3.2 & 2.4 & 2.1 & 1.4 & 1.5 & 1.3 \\
\hline Six East Asian traders & 3.0 & 2.6 & 2.4 & 3.4 & 5.8 & 9.7 & 10.0 \\
\hline Other Asia & 5.8 & 4.5 & 3.1 & 2.1 & 2.7 & 2.6 & 3.0 \\
\hline GATT/WTO Members b & 60.4 & 68.7 & 72.8 & 81.8 & 76.0 & 86.9 & 89.7 \\
\hline \multicolumn{8}{|c|}{$\begin{array}{c}\text { Import } \\
\text { Value } \\
589.0 \\
\text { Share }\end{array}$} \\
\hline World & 100.0 & 100.0 & 100.0 & 100.0 & 100.0 & 100.0 & 100.0 \\
\hline North America & 19.8 & 19.7 & 15.5 & 16.7 & 17.8 & 19.8 & 22.3 \\
\hline Latin America & 10.6 & 9.3 & 6.8 & 5.1 & 4.5 & 5.2 & 5.8 \\
\hline Western Europe & 40.4 & 39.4 & 45.4 & 47.4 & 40.0 & 42.9 & 42.2 \\
\hline $\begin{array}{l}\text { C./E. Europe/Baltic State/ C } \\
\text { a }\end{array}$ & 5.8 & 7.6 & 10.3 & 8.9 & 8.4 & 2.9 & 3.7 \\
\hline Africa & 7.6 & 7.0 & 5.5 & 4.0 & 4.6 & 2.6 & 2.3 \\
\hline Middle East & 1.7 & 2.0 & 2.3 & 2.8 & 6.3 & 3.2 & 2.6 \\
\hline Asia & 14.2 & 15.1 & 14.2 & 15.1 & 18.5 & 23.4 & 20.9 \\
\hline Japan & 1.0 & 2.9 & 4.1 & 6.5 & 6.7 & 6.4 & 5.4 \\
\hline China & 1.1 & 1.7 & 0.9 & 0.9 & 1.1 & 2.8 & 2.9 \\
\hline Australia and New Zealand & 2.6 & 2.4 & 2.3 & 1.6 & 1.4 & 1.5 & 1.5 \\
\hline Six East Asian traders & 3.0 & 3.4 & 3.1 & 3.7 & 6.1 & 9.9 & 8.5 \\
\hline Other Asia & 6.5 & 4.7 & 3.8 & 2.3 & 3.1 & 2.8 & 2.7 \\
\hline GATT/WTO Members & 52.9 & 66.0 & 74.2 & 89.1 & 83.9 & 91.0 & 91.6 \\
\hline
\end{tabular}

a Figures are significantly affected by: (i) changes in the country composition of the region and major adjustment in trade conversion factors between 1983 and 1993; and (ii) the inclusion of the Baltic States and the CIS mutual trade between 1993 and 1999.

b Membership as of the year stated.

Note: Between 1973 and 1983 and between 1993 and 1999 export and import shares were significantly influenced by oil price developments. 
One of the indicators of the role of external trade is the relation between the value of exports and imports according to the total GDP. On a global scale, this indicator is over $40 \%$. Almost in all EU countries, annual export and import volumes exceed 50\% of GDP. Only in the US and Japan, the foreign trade quota is lower (around $1 / 4$ GDP in the US and around 1/5 of GDP in Japan). In the second half of the twentieth century, world trade achieved much faster growth than world GDP, especially per capita. For 1950-1995. GDP of the world grew by 6 times, industrial production by 7.4 times, and merchandise exports by $12.8 \%$ (at constant prices), while at the same time the growth of world GDP per capita was considerably more modest $(1.4 \%)$. At the end of the 20th century, the highest GDP revenues were made by the United States, which was a symbol and an example of world trade throughout the XX. (United Nations Development Program, 2001).

Table no. 2: GDP in the world's largest economies in 1999 (billion USD)

\begin{tabular}{|c|c|}
\hline COUNTRY & GDP \\
\hline USA & $8,710,000,000,000.00$ \\
\hline Japan & $4,395,000,000,000.00$ \\
\hline Germany & $2,081,200,000,000.00$ \\
\hline France & $1,410,000,000,000.00$ \\
\hline UK & $1,373,600,000,000.00$ \\
\hline Italy & $1,150,000,000,000.00$ \\
\hline China & $996,300,000,000.00$ \\
\hline Brazil & $791,400,000,000.00$ \\
\hline Canada & $612,000,000,000.00$ \\
\hline Mexico & $483,000,000,000.00$ \\
\hline India & $447,000,000,000.00$ \\
\hline Russia & $184,000,000,000.00$ \\
\hline Indonesia & $151,000,000,000.00$ \\
\hline Israel & $99,000,000,000.00$ \\
\hline
\end{tabular}

Table no. 2 made by authors based on the United Nations Development Program (2001) presents GDP in the World's largest economies in 1999 year. At the end of the 20th century, the US had the largest GDP in the world with 8,710 bln. USD. The US is followed by Japan and European Union countries (Germany, France, UK, Italy). China, as a developing country, had the largest GDP in the world.

Through dynamic analysis, we will show if there is a significant difference between imports by regions and developed countries for the period 1980-1999 years.

Chart no. 1 shows the structure of import values by region for the period 1980-1999 years, based on the WTO statistics (International trade statistics, 2000). Here we can see comparative statistics of several independent variables during the observed period. In the period from 1980 to 1999, the import of goods by 
region and developed countries varies from year to year. Chart no. 1 presents that total commodity trade tends to grow from 1980 to 1998, while this growth is most significant for Six East Asian traders during the analyzed period. It should also be noted that China had a significant increase in imports in 1998 and 1999 compared to 1980 and 1990.

Chart no. 1: Import structure by countries and regions for the period 1980-1999 (in bln. \$)

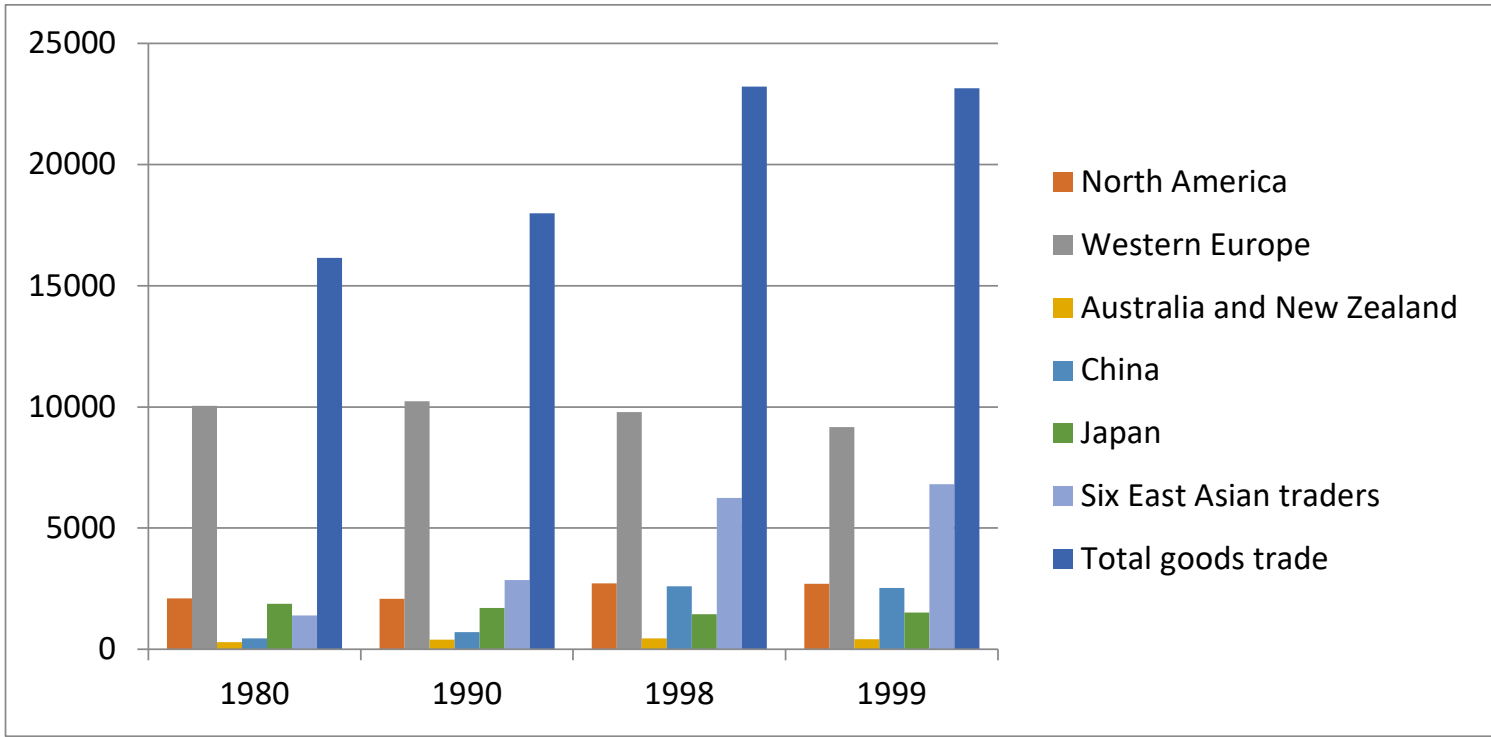

Chart no. 2: Evolution of imports by countries and regions for the period 1980-1999 (in bln. \$)

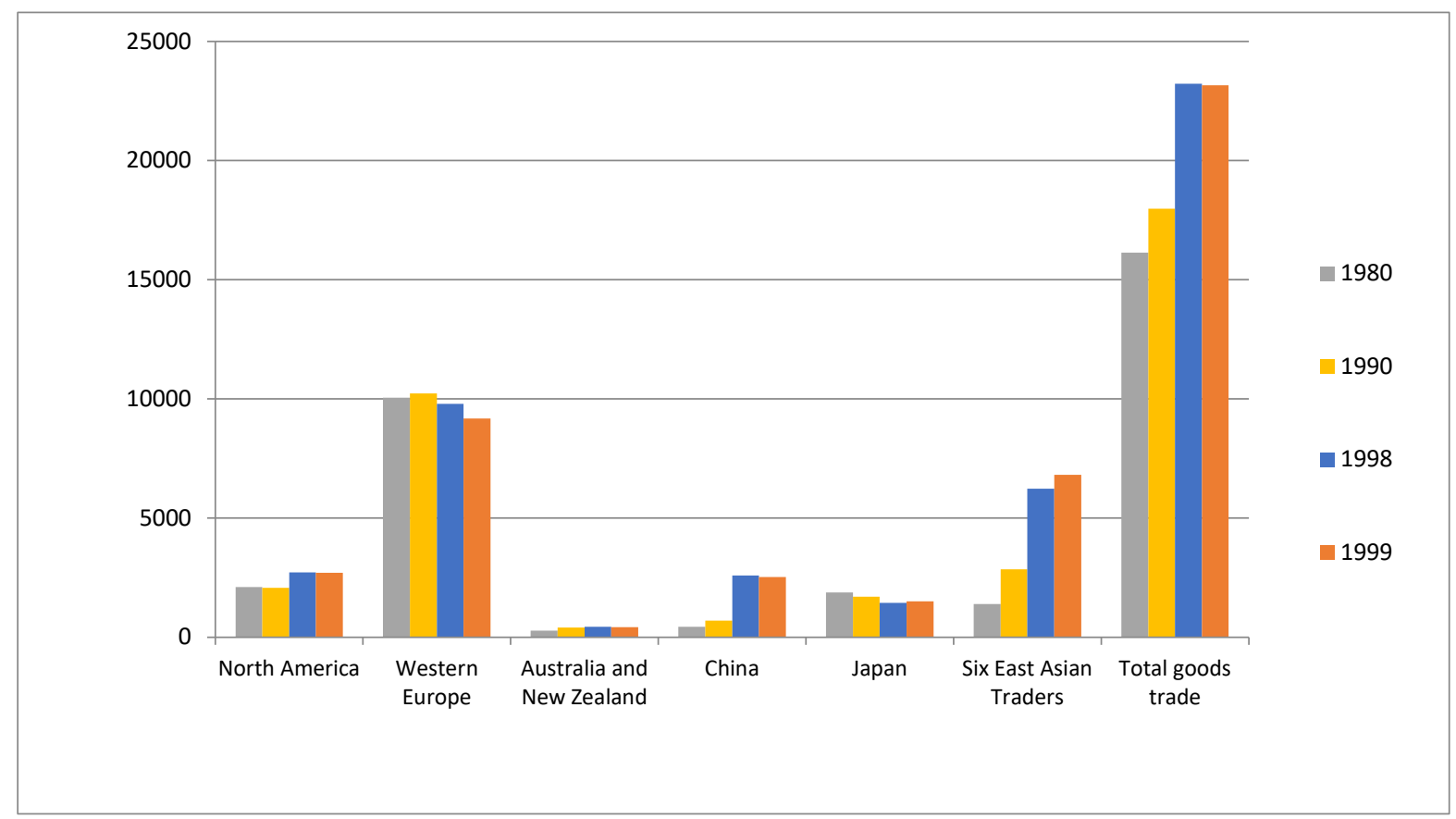


In the Chart no. 2, formed on the WTO statistics (International trade statistics, 2000) we can see the evolution of imports of goods by region. At the same time, in this chart, we can highlight that Western Europe and the Six East Asian traders dominate the total commodity trade during the analyzed countries and regions.

To determine the significance of the differences between imports by countries and regions, and over time, the base and chain indices will be used in the continuation of the research.

The index is calculated based on the charts no.1 and no.2 by the formula: $I(b i)=Y i / Y_{0}^{*} 100$.

Table no. 3. Calculation of base index numbers for import movements by countries and regions for the 19801999 period

\begin{tabular}{|l|r|r|r|r|}
\cline { 2 - 5 } \multicolumn{1}{c|}{} & \multicolumn{4}{c|}{ Base Year Index } \\
\cline { 2 - 5 } \multicolumn{1}{c|}{} & $\mathbf{1 9 8 0}$ & $\mathbf{1 9 9 0}$ & $\mathbf{1 9 9 8}$ & $\mathbf{1 9 9 9}$ \\
\hline North America & 100 & 98.86 & 129.24 & 128.8 \\
\hline Western Europe & 100 & 101.9 & 97.461 & 91.34 \\
\hline $\begin{array}{l}\text { Australia and } \\
\text { New Zealand }\end{array}$ & 100 & 141.4 & 156.14 & 147.7 \\
\hline China & 100 & 158.5 & 581.17 & 567 \\
\hline Japan & 100 & 91.09 & 76.841 & 80.68 \\
\hline $\begin{array}{l}\text { Six East Asian } \\
\text { traders }\end{array}$ & 100 & 205.5 & 448.71 & 490 \\
\hline Total goods trade & 100 & 111.4 & 143.84 & 143.4 \\
\hline
\end{tabular}

In the Table no. 3, for all observed countries, we took the base year of the 1980s. In 1999, only Western Europe (by 8.66\%) and Japan (19.32\%) recorded a decline in imports compared to the 1980s. Characteristically, China (467.04\%) and Six East Asian traders recorded an incredible growth rate (390\%) of imports from 1980 to 1999.

The chain index has been calculated based on the charts no. 1 and 2 by the formula: $I(v i)=Y i / Y i-1$ * 100. 
Table no. 4: Calculation of chain index swords for movements of imports by countries and regions for the 1980-1999 period

\begin{tabular}{|l|r|r|r|r|c|}
\cline { 2 - 5 } \multicolumn{1}{c|}{} & \multicolumn{4}{c|}{ Chain Base Index } & \multirow{2}{*}{$\begin{array}{c}\text { The average annual } \\
\text { rate of change }\end{array}$} \\
\cline { 2 - 5 } & $\mathbf{1 9 8 0}$ & $\mathbf{1 9 9 0}$ & $\mathbf{1 9 9 8}$ & $\mathbf{1 9 9 9}$ & 8.79 \\
\hline North America & $/$ & 98.86 & 130.74 & 99.63 & -2.97 \\
\hline Western Europe & $/$ & 101.9 & 95.68 & 93.72 & 13.89 \\
\hline $\begin{array}{l}\text { Australia and } \\
\text { New Zealand }\end{array}$ & $/$ & 141.4 & 110.42 & 94.61 & 78.32 \\
\hline China & $/$ & 158.5 & 366.62 & 97.57 & -6.90 \\
\hline Japan & $/$ & 91.09 & 84.359 & 105 & 69.85 \\
\hline $\begin{array}{l}\text { Six East Asian } \\
\text { traders }\end{array}$ & $/$ & 205.5 & 218.38 & 109.2 & 12.78 \\
\hline Total goods trade & $/$ & 111.4 & 129.13 & 99.72 & \\
\hline
\end{tabular}

If we look at the 1998 year (Table no. 2), we can conclude that:

- North America in that year had the highest import rate among the analyzed countries and regions, which is $30.74 \%$ higher than in 1990, while in 1999 it decreased by $0.37 \%$ compared to 1998 .

- In the observed year, Western Europe recorded a decline in imports compared to 1990, by $4.32 \%$, while this decline continued in 1999 and amounted to $1.28 \%$ in comparison with the previous year.

- Australia and New Zealand had an increase in imports in 1998 compared to the 1990 s by $10.42 \%$, while in 1999 there was a decline in the import rate of 5.39\%.

- In the observed year, China had significant growth, by $266.62 \%$ in the import level compared with 1990, while in 1999 it was evident that the rate was down by $2.43 \%$ in comparison with 1998.

- In the analyzed year, Japan recorded a decline in the import rate of about $15.64 \%$ compared to 1990, while in 1999 it increased by 5\% compared to 1998. Since the import rate for the Six East Asian traders had a continuous growth within the period 1980-1999, the import rate in 1998 increased by $118.38 \%$ on the 1990 s ratio, while in 1999 it increased by $9.20 \%$ compared to the previous year. In the observed year, the total commodity trade had an increase in the import level compared to 1990 by about $29.13 \%$, while already in 1999 it recorded a slight decrease in imports by about $0.28 \%$, comparing it with 1998 .

If we look at the average annual rate of change in imports from 1980-1999, we see that China has the strongest average annual rate of change in imports (78.32\%), while Japan records the negative, lowest average annual rate of change of imports (-6.90). The average annual rate of change in the total commodity trade is $12.78 \%$. 
Further, we will evaluate the regression model and test its validity for the import of the countries and regions that are the subject of this research for the observed period (chart no. 3), based on the related information (data in tables no. 1 and 2) through the coefficient of determination testing of hypotheses.

Chart no. 3: Model of the linear trend for import trends by countries and regions for the 1980-1999 periods (in bln. $\$$ and by the coefficient of determination)

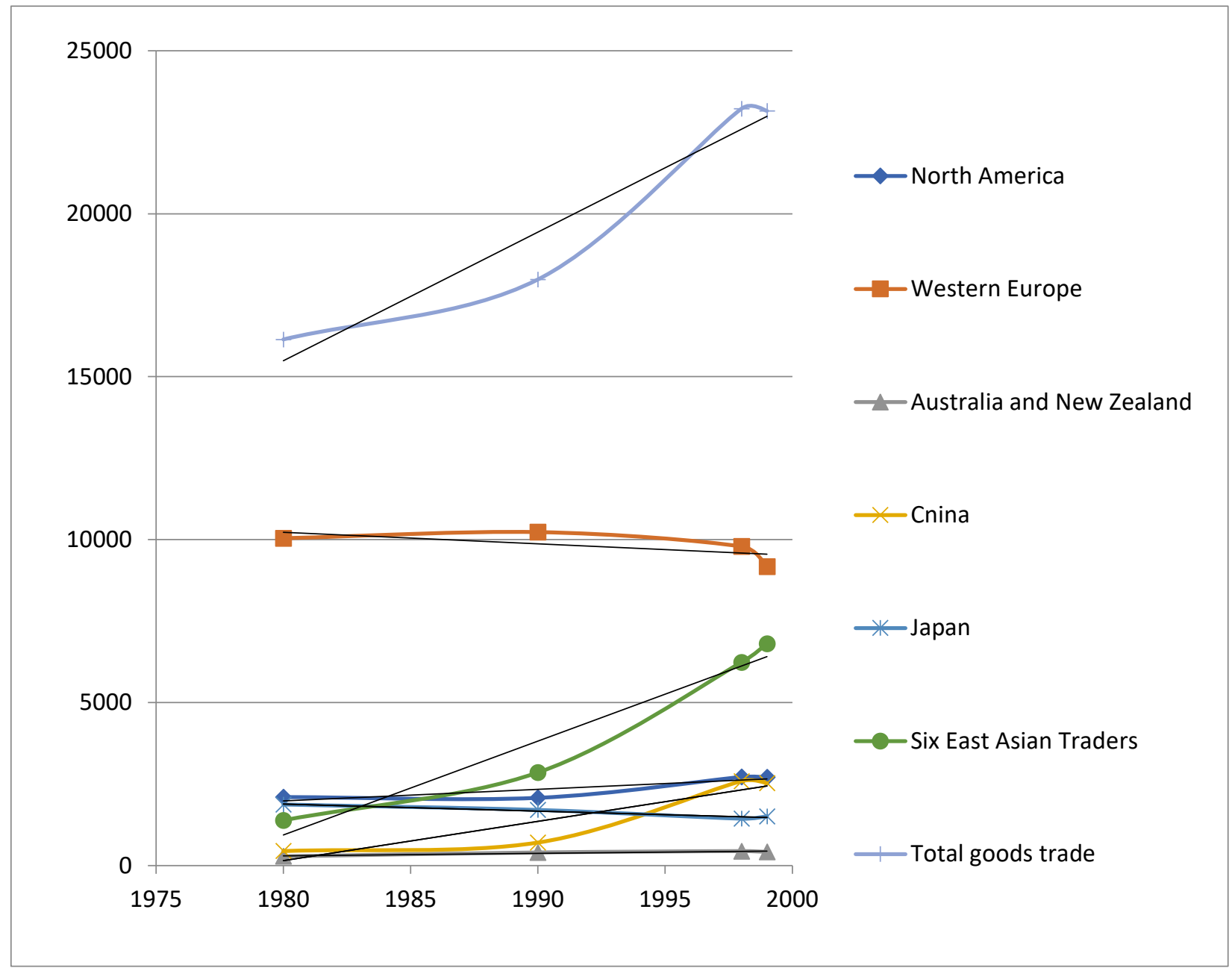

A high coefficient of determination (R2) indicates the validity and representatively of the regression model, i.e., which is the value of the coefficient closer to the unit, the regression model is well placed.

In the Table no. 5, made by authors, we see that the value of the coefficient of determination in the case of commodity imports in Japan is 0.9471 . This means that the linear model in which the independent variable is the time, explains $94.71 \%$ of the variation of total imports of Japan. However, in the linear trend forecast for goods imports in Western Europe, the coefficient of determination are far lower (45.67\%), so the linear trend model is not adequate in this case. 
Table no. 5. Calculation of the model of the linear trend and coefficient of determination for the movement of imports by countries and regions for the 1980-1999 period

\begin{tabular}{|l|c|c|}
\hline \multicolumn{1}{|c|}{ Goods imports trend } & Linear trend model & Coefficient of determination \\
\hline Total goods trade & $\mathrm{Y}=394.66 \mathrm{X}-765930$ & $\mathrm{R}^{2}=0.9244$ \\
\hline Western Europe & $\mathrm{Y}=-35.353 \mathrm{X}+80226$ & $\mathrm{R}^{2}=0.4567$ \\
\hline Six East Asian traders & $\mathrm{Y}=287.99 \mathrm{X}-569288$ & $\mathrm{R}^{2}=0.9367$ \\
\hline North America & $\mathrm{Y}=35.54 \mathrm{X}-68385$ & $\mathrm{R}^{2}=0.7592$ \\
\hline Japan & $\mathrm{Y}=-21675 \mathrm{X}+44804$ & $\mathrm{R}^{2}=0.9471$ \\
\hline Australia and New Zealand & $\mathrm{Y}=7.6455 \mathrm{X}-14840$ & $\mathrm{R}^{2}=0.8968$ \\
\hline China & $\mathrm{Y}=120.55 \mathrm{x}+238533$ & $\mathrm{R}^{2}=0.8515$ \\
\hline
\end{tabular}

And when the export is concerned, we will use dynamic analysis to show if exports differ significantly in regions and developed countries for the period 1980-1999 years.

Chart no. 4: Structure of exports by countries and regions (in bln. \$)

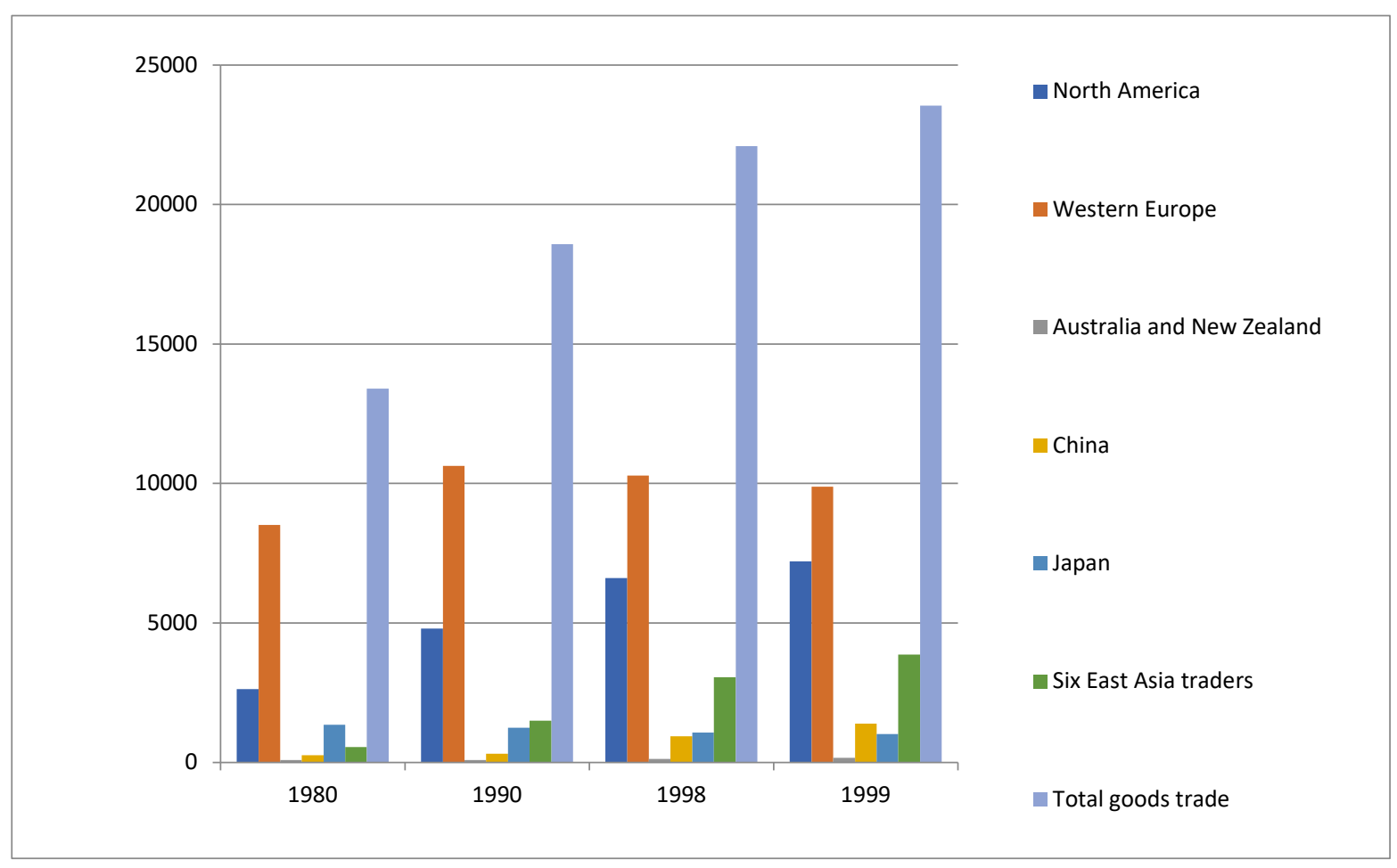


Chart no. 5: Export evolution for the period 1980-1999 by countries and regions (in bln. \$)

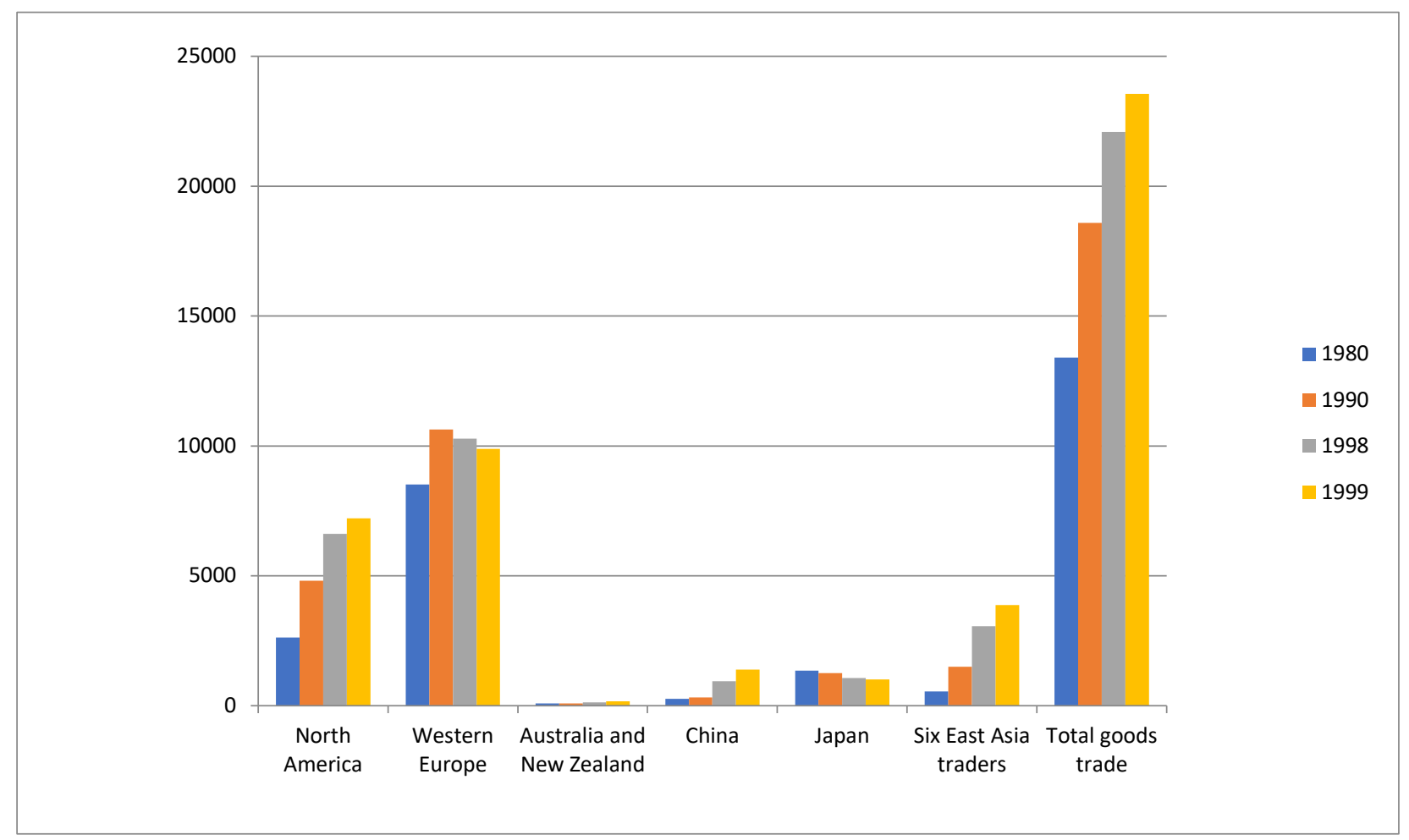

Chart no. 4, designed based on WTO statistics (International trade statistics, 2000) shows that for the period 1980-1999. Western Europe and North America had the largest share in total trade in exports when it comes to trade, followed by Six East Asian traders and Japan.

Chart no. 5 shows the evolution of exports by region using the International trade statistics (2000). Analyzing the evolution of exports for the observed period, we can notice that exports of total commodity trade are on a constant increase from year to year. Also, we can see that the situation is the same with North America, Six East Asian Trader Countries, and China. In 1980, Japan recorded the highest export value, and each following year exports declined. Western Europe recorded the highest export value in 1990, while Australia and New Zealand in 1999 had the highest export value. 
Table no. 6. Calculating base indexes numbers for export trends by country of export movement numbers by country and regions for the $1980-1999$ period

\begin{tabular}{|l|r|r|r|r|}
\cline { 2 - 5 } \multicolumn{1}{c|}{} & \multicolumn{4}{c|}{ Base Year Index } \\
\cline { 2 - 5 } \multicolumn{1}{c|}{} & 1980 & 1990 & 1998 & 1999 \\
\hline North America & 100 & 183.1 & 251.9 & 274.6 \\
\hline Western Europe & 100 & 124.9 & 120.8 & 116.1 \\
\hline Australia and New Zealand & 100 & 93.48 & 133.7 & 188 \\
\hline China & 100 & 119.8 & 359.9 & 532.8 \\
\hline Japan & 100 & 92.18 & 78.83 & 74.85 \\
\hline Six East Asian traders & 100 & 269.8 & 550.7 & 696.2 \\
\hline Total goods trade & 100 & 138.7 & 164.9 & 175.7 \\
\hline
\end{tabular}

Table no. 7. Calculating chain index numbers for export trends by country of export movement numbers by country and regions for the 1980-1999 period

\begin{tabular}{|l|r|r|r|r|c|}
\cline { 2 - 6 } \multicolumn{1}{c|}{} & \multicolumn{4}{c|}{ Chain Base Index } & \multirow{2}{*}{$\begin{array}{c}\text { Average annual } \\
\text { rate of change }\end{array}$} \\
\cline { 2 - 6 } \multicolumn{1}{c|}{} & & $\mathbf{1 9 9 0}$ & $\mathbf{1 9 9 8}$ & $\mathbf{1 9 9 9}$ & 40.03 \\
\hline North America & $/$ & 183.1 & 137.6 & 109 & 5.12 \\
\hline Western Europe & $/$ & 124.9 & 96.75 & 96.11 & 25.76 \\
\hline China & $/$ & 93.48 & 123 & 173 & 74.66 \\
\hline Japan & $/$ & 119.8 & 300.3 & 148 & -9.20 \\
\hline Six East Asian tradia and New Zealand & $/$ & 92.18 & 85.52 & 94.95 & 90.95 \\
\hline Total goods trade & $/$ & 269.8 & 204.1 & 126.4 & 20.67 \\
\hline
\end{tabular}

We analyzed (table no. 6) the percentage of export changes compared to the base year 1980. The Six East Asian traders achieved the highest increase in exports in the analyzed period, by $596.2 \%$ in 1999 compared to 1990. The Six East Asian Trader Countries is followed by China (432.8\%) and North America (174.6\%). Only Japan, from the countries and regions subject to this analysis, had a decline in exports in 1999 compared to the 1980 s, by $25.15 \%$. Australia and New Zealand, although they have the smallest share in the total commodity trade, registered an increase in exports compared to the base year, by $88 \%$.

Analyzing the chain indices (table no. 7), we can distinguish China's significant export growth rate, especially in 1998 when compared to 1990 , by $200.3 \%$, while Japan declined by $14.48 \%$ in the same period. 
The average annual rate of export change for the Six East Asian Trader Countries is $90.95 \%$, which indicates not only an increase in exports annually but that the value of exports in each subsequent year is almost twice as high as in the previous year. Also, China has a very high average annual rate of export change, which equals $74.66 \%$, while Japan has an average annual export rate of $9.2 \%$ on average over the previous year.

For import, so for export, we will evaluate the regression model and test its validity for the countries and regions that are the subject of this paper for the period 1980-1999 (chart no. 6).

Chart no. 6: Model of the linear trend for export trends by countries and regions for the 1980-1999 period (in bln. \$ and by the coefficient of determination)

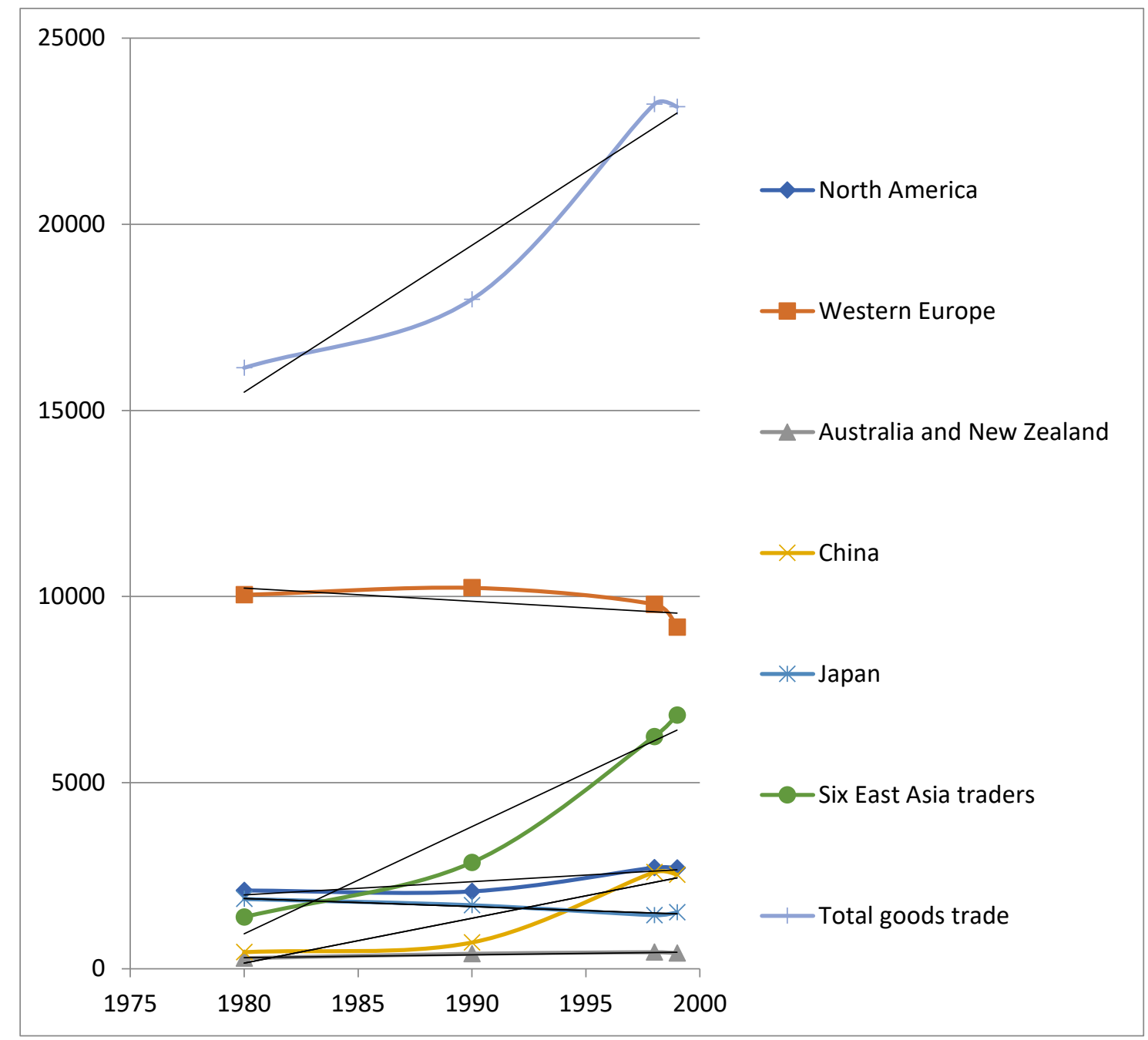

We can see (table no. 8) that the Coefficient of Determination (R2) is close to 1 for the Total Commodity Trade (0.9926) and North America (0.9938), which means that almost $100 \%$ of the total export variability was the result of variations in time. The linear trend model for Western Europe is not applicable, since the coefficient 
of determination is 0.4989 . This means that the independent variable (time) does not explain a sufficient percentage of the total variation export of Western Europe and that about $50.11 \%$ of variations are not the result of the influence of time, but other variables that are not included in the model and other random factors. The regression model is also well placed for Six East Asian traders and Japan.

Table no. 8. Calculation of linear trend model and determination coefficient for export trends by countries and regions for the 1980-1999 period

\begin{tabular}{|l|l|l|}
\hline Goods exports trend & Linear trend model & Coefficient determination \\
\hline Total goods trade & $\mathrm{Y}=510.54 \mathrm{x}-997458$ & $\mathrm{R}^{2}=0.9926$ \\
\hline Western Europe & $\mathrm{Y}=74.504 \mathrm{x}-138566$ & $\mathrm{R}^{2}=0.4989$ \\
\hline Six East Asian traders & $\mathrm{Y}=163.46 \mathrm{x}-323315$ & $\mathrm{R}^{2}=0.9255$ \\
\hline North America & $\mathrm{Y}=233.44 \mathrm{x}-459642$ & $\mathrm{R}^{2}=0.9938$ \\
\hline Japan & $\mathrm{Y}=-17.532 \mathrm{x}+36091$ & $\mathrm{R}^{2}=0.9513$ \\
\hline Australia and New Zealand & $\mathrm{Y}=3.4006 \mathrm{x}-66547$ & $\mathrm{R}^{2}=0.5668$ \\
\hline China & $\mathrm{Y}=53.219 \mathrm{x}-105270$ & $\mathrm{R}^{2}=0.7483$ \\
\hline
\end{tabular}

Chart no. 7 shows the movement of the average annual rate of change in imports and exports based on the International trade statistics (2000). We see that in each country/region, exports are from year to year.

Chart no. 7. Comparison of the average annual rate of change for imports and exports of countries and regions for the period from 1980 to 1999.

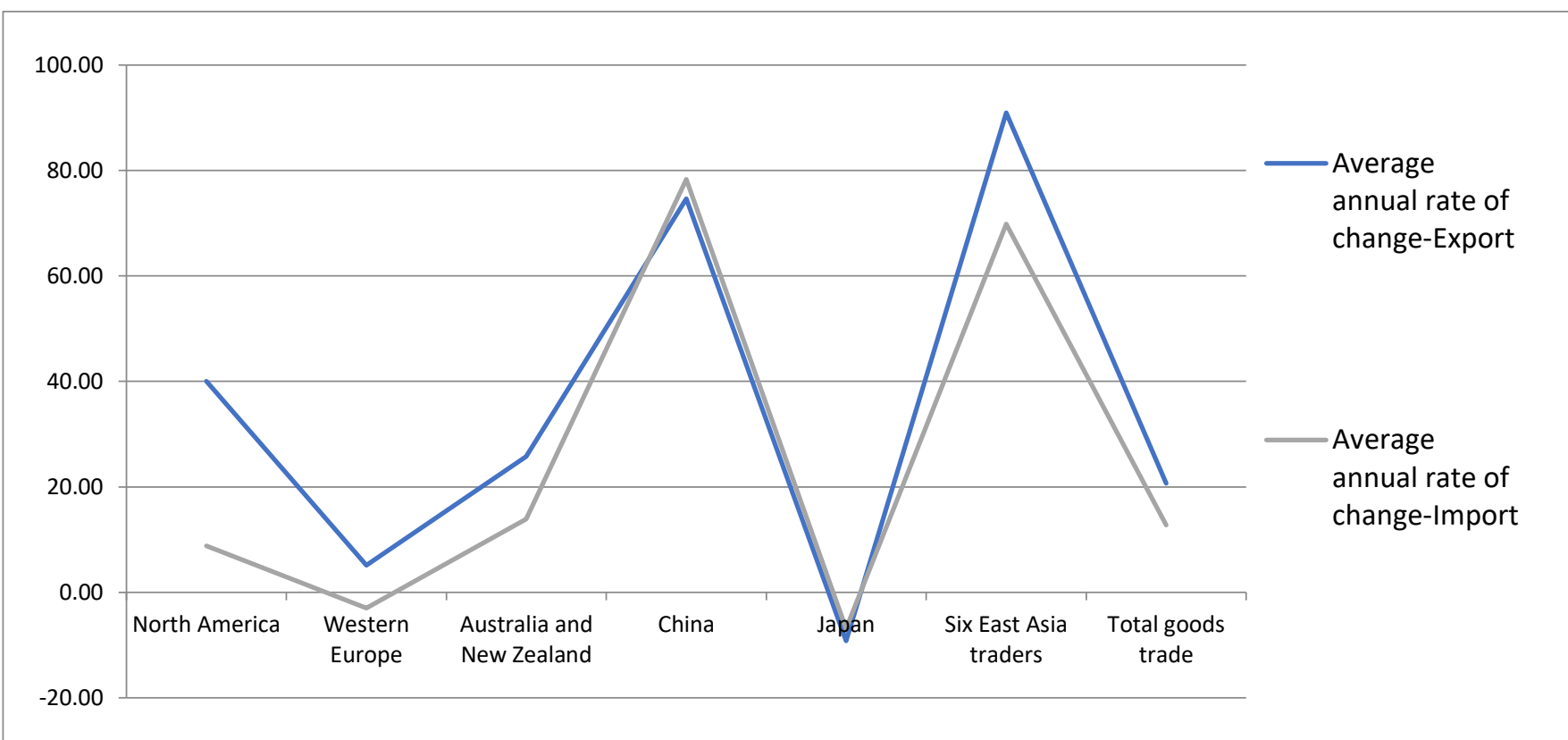


The conclusion is that China and Six East Asian traders have significant growth both for imports and exports on an annual basis from all observed countries and regions, observing the period from 1980 to 1999. On the other hand, Japan has distinguished itself as a country that, for the same analyzed period, had a negative average annual rate of change in both imports and exports.

\section{CONCLUSIONS}

For the international economy, trade and financial relations among national economies are important, as well as the impact of international trade and finance on the distribution of production, income, and wealth worldwide and among countries. In the period from 1948 to 1999, average exports and imports of goods were higher than in developed countries than in developing countries. The same growth was higher between 1983 and 1999. Based on the conducted analysis, we can conclude that there is a significant difference in imports and exports between the countries and regions that are observed. Also, this difference is noticeable when a particular country is viewed over time. The above conclusion is supported by the results obtained through the base and chain index numbers as well as the results of the average annual rate of change.

FUNDING: The authors did not receive any external funding.

CONFLICT OF INTEREST: The authors declare no conflicts of interest.

\section{REFERENCES}

1. Balšić Smiljana, 2014. "Makroekonomski aspekti međunarodne trgovine", Ekonomija teorija i praksa, 7 (1), pp. 53-68. Available at: https://scindeks-clanci.ceon.rs/data/pdf/2217-5458/2014/221754581401053B.pdf

2. Dragutinović-Mitrović R.; Bošković O., 2016. “Osnovi statističke analize-Elementi analize vremenskih serija”, sedmo izdanje, Ekonomski fakultet Beograd.

3. Emina Resić, 2012. "Statističke metode za donošenje odluka”, Priručnik, Ekonomski fakultet, Univerzitet Sarajevo. 
4. Mann S., 2009. "Introduction into statistics - the sixth edition, translated edition", School of Economics Belgrade, Belgrade.

5. Ohlin, B., 1933. Interregional and International Trade. Cambridge: Harvard University Press.

6. Rybczynski, T.M., 1955. "Factor Endowments and Relative Commodity Prices". Economica 22, 33641.

7. Samuelson, P. A., 1948. "International Trade and the Equalization of Factor Prices". Economic Journal 58, 163-84.

8. Samuelson, P. A., 1949. "International Factor-Price Equalization Once Again”. Economic Journal 59, 181-97.

9. United Nations Development Program, 1999. Human development report 1999, Available at: http:/hdr.undp.org/sites/default/files/reports/260/hdr_1999_en_nostats.pdf (accessed march 13, 2016).

10. United Nations Development Program, 2001. Human development report 2001. Available at: http://hdr.undp.org/sites/default/files/reports/262/hdr_2001_en.pdf (accessed march 13, 2016).

11. International trade statistics, 2000. World Trade Organization - WTO. Available at: https://www.wto.org/english/res e/statis_e/stats2000_e.pdf (accessed march 13, 2016). 